Research Article

\title{
Access to Optimal Calcination Temperature for Nanoparticle Synthesis from Hydroxyapatite Bovine Femur Bone Waste
}

\author{
Ali Sabea Hammood ${ }^{1 \llbracket}$, Sora Salem Hassan ${ }^{1}$, Mohammed Talib Alkhafagy ${ }^{2}$ \\ ${ }^{1}$ Department of Material Engineering, Faculty of Engineering, University of Kufa, Iraq. \\ ${ }^{2}$ Faculty of Dentistry, University of Kufa, Iraq. \\ Corresponding author. E-mail: alis.altameemi@uokufa.edu.iq
}

Received: Jun. 30, 2017; Accepted: Sep. 13, 2017; Published: Sep. 27, 2017.

Citation: Ali Sabea Hammood, Sora Salem Hassan, and Mohammed Talib Alkhafagy, Access to Optimal Calcination Temperature for Nanoparticle Synthesis from Hydroxyapatite Bovine Femur Bone Waste. Nano Biomed. Eng., 2017, 9(3): 228-235.

DOI: $10.5101 /$ nbe.v9i3.p228-235.

\begin{abstract}
Hydroxyapatite (HAp) is one of the vital and bioactive materials that are commonly used in biomedical field and concentrated in clinical area. It is a bio-ceramic powder synthesized by using different bio-waste materials such as bovine femur bone. In this study, the bovine femur bone powder was prepared to obtain nano powder. The purpose of this study was to reach the optimal temperature to obtain nanoparticles HAp. The resulted powder was calcinated in a furnace at different temperatures $\left(900,950,1000,1050\right.$ and $1100{ }^{\circ} \mathrm{C}$ ) for $2 \mathrm{~h}$ at the heating rate of $10^{\circ} \mathrm{C} / \mathrm{min}$ and cooled slowly in a furnace. Results showed, the formation of pure HAp by the presence of peaks corresponding to $\left(\mathrm{PO}_{4}\right)^{3-}$ at $632 / \mathrm{cm}$ and $\mathrm{OH}^{-}$at $3,572 / \mathrm{cm}$ in fourier transformation infrared spectroscopy (FTIR). For the calcined samples, there were three main peaks of 211,112 and 300 planes at $2 \theta$ near 31.8, 32.2 and 32.9 respectively. The amorphous raw bones were transformed into crystalline phase and the lattice parameters for HAp c and a were calculated in X-ray diffraction (XRD), Raman analysis showed that the calcination process removed the organic compound from the bovine femur bones matrix. Scanning electron microscopy (SEM) and energy dispersive X-ray analysis (EDX) showed that the shape of the granules was irregular, containing quantities of oxygen, magnesium, sodium and carbon; the ratio of calcium to phosphate was calculated, Atomic force microscopy (AFM) showed that the particles sizes ranged from nanometers to microns. EDX result found that the calcium to phosphate ratio reached 1.7058 after calcination at $950{ }^{\circ} \mathrm{C}$ which was close to stoichiometric hydroxyapatite (1.67). This result implied the formation of pure HAp phase at $950^{\circ} \mathrm{C}$.
\end{abstract}

Keywords: Hydroxyapatite; Bovine femur bone; Calcination temperature

\section{Introduction}

Hydroxyapatite ( $\left.\mathrm{HAp}, \mathrm{Ca}_{10}\left(\mathrm{PO}_{4}\right)_{6}(\mathrm{OH})_{2}\right)$ is among the few materials that are classified as bioactive, meaning that it will support bone in growth and osseointegration [1]. The chemical and structural similarity of HAp with bone minerals has proven to be hydroxyapatite, an attractive biomaterial for bone and tooth implantation. Hydroxyapatite is highly biocompatible with human organs. It has acknowledged a great consideration in the field of biomedical science due to its ability to form chemical bonds between hard tissues [2]. Bones consist of organic $(30 \%)$ and inorganic compounds $(70 \%)$. 
Mineral parts of bones provide their stiffness and proper mechanical properties. The model compound corresponding to a mineral phase of bones is a nonstoichiometric hydroxyapatite (HAp), i.e. HAp whose molar ratio of calcium to phosphorus is different to 1.67. Biological apatite are the components of bones and also pathological tissue (urolith, tooth scale and mineralized soft tissue) [3]. There are many applications of the HAp such as to bone and tooth defect filling, tooth pastes and bone cement, biocompatible and bioactive coatings on metal implants for dental implants, hip joint prosthesis and others [4]. Because of the attractive properties of HAp powders, various techniques have been and are being developed to produce hydroxyapatite. There are two main ways of obtaining HAp; one is through inorganic synthesis and the other way is to obtain HAp from natural sources [5]. Several methods which have been developed to synthesis HAp powders can be classified as either wet chemistry methods or solid-state reactions [6]. The main component of synthetic HAp is calcium. Calcium needed for the preparation of HAp from living bodies reduces the chance of impurities and the cost of production. Various natural sources like bovine bone, corals, fish bone and egg shells have been recognized so far due to their advantage of biological origin as well as a method to recycle inorganic waste [7]. In recent years, the use of bio-HAp has increased. Biomaterial also has other elements that are present in the human HAp. Although ions are found in the bone in small amounts, these ions are very important to biological reactions related with bone metabolism $[8,9]$. The aim of this work is to approach the optimal temperature to obtain nanoparticles hydroxyapatite from the bovine femur bone.

Recently, Lü et al., showed that the calcining method of high temperature was effective and feasible for the preparation of natural HAp from pig bones and pig teeth [10]. Commercial Bio-HAp has been studied by Figuereido et al., fourteen different samples were used in dentistry, three of them based on HAp and the others based on calcium carbonate [11]. Kupiec et al. studied the effect of calcination parameters on bone hydroxyapatite in artificial saliva and its biosafety. The X-ray diffraction (XRD) analysis of HAp confirmed the stability of the material [12]. Chenab et al. found that the performances of calcium phosphates in application depended greatly on their morphologies, structures and chemical compositions. These nanostructured calcium phosphates are promising biomaterials for applications in tissue engineering scaffolds, drug/gene delivery and other medical areas [13]. Nosoudi et al. found the hydroxyapatite containing $35 \mu \mathrm{g}$ etidronate showed low early strength, but high strength after soaking in simulated body fluid (SBF) [14]. Jaber et al., utilized the camelus bone to synthesize HAp powders, and the results showed that powders obtained at calcination temperature $\left(1000{ }^{\circ} \mathrm{C}\right)$ was a pure $\mathrm{HAp}$ with the $\mathrm{Ca} / \mathrm{P}$ ratio of 1.6557 [15]. The aim at this work is to approach the optimal temperature to obtain hydroxyapatite nanoparticles from the bovine femur bone.

\section{Experimental \\ Materials and methods Bovine femur bone preparation}

Bovine femur bone was collected from the local butcher. The femur bone were extracted from the bovine bone, boiled in distilled water for $1 \mathrm{~h}$ and washed using a fast flow water jet to eliminate the organic and proteins materials. The raw bovine femur bone was cut by grinding, mortar pestle into powder, and left to be sun-dried for 2 weaks. It was crushed in a planetary mill (SFM-1(QM-3SP2)) which was equipped with alumina balls of different sizes at 4,000 $\mathrm{rpm}$ for $8 \mathrm{~h}$. Particle size analysis for the powder before and after crushing was established by laser particle size analyzer.

\section{Calcination process}

In the calcination process, $10 \mathrm{~g}$ of bovine femur bone powder sample was placed in an open alumina crucible. All samples were heated at various temperatures of $900{ }^{\circ} \mathrm{C}, 950{ }^{\circ} \mathrm{C}, 1000{ }^{\circ} \mathrm{C}, 1050{ }^{\circ} \mathrm{C}$ and $1100{ }^{\circ} \mathrm{C}$ for $2 \mathrm{~h}$ at the heating rate of $10{ }^{\circ} \mathrm{C} / \mathrm{min}$ and afterward cooled slowly in a furnace to room temperature.

\section{Characterization of the synthesized bovine femur bone Fourier transform infrared spectroscopy (FTIR)}

FTIR-SHIMADSO (Japan) is a powerful tool for identifying the types of chemical bonds in a molecule and functional groups obtained at different temperatures by producing an infrared absorption spectrum. The synthesized powder was mixed with spectroscopic grate potassium bromide ( $\mathrm{KBr}$ ). 1-2 mg of HAp powder sample was mixed with $200 \mathrm{mg}$ of $\mathrm{KBr}$ powder. The spectra were registered on the $400-4,000 / \mathrm{cm}$ regions 
using 20 scans and a spectral resolution of $4 / \mathrm{cm}$.

\section{X-ray diffraction (XRD)}

The crystalline structure and the phase composition of the raw powder before and after calcination were determined by using XRD (XRD-6000 SHIMADZU, Japan, ICDD00-024-0033). $\mathrm{CuK} \alpha$ radiation $(\lambda=$ $0.154056 \mathrm{~nm}$ ) was employed, with voltage $=40 \mathrm{kV}$ and current $=30 \mathrm{~mA}$; data were collected over the $2 \theta$ from $10^{\circ}$ to $50^{\circ}$ (Bragg angle). From XRD the (hkl) planes and the values of lattice parameters $\mathrm{c}$ and a could be calculated.

\section{Raman spectroscopy}

In order to explore any structural changes in substitutions in the apatite lattice, Raman spectroscopy (Raman-Bruker Senterra model, Germany) was used with the wave lengths of $532 \mathrm{~nm}$ and $758 \mathrm{~nm}$.

\section{Scanning electron microscopy (SEM)}

The morphology or microstructure of bovine femur bone before and after calcination process was observed under a scanning electron microscope (SEM-FEI Quanta model, Holland) at an acceleration of $12.5 \mathrm{kV}$. The local chemical compositions of raw powder before and after calcination process were analyzed by using energy dispersive spectroscopy (EDS), which was regarded as an auxiliary for SEM.

\section{Atomic force microscopy (AFM)}

The surface morphology, particle shape, particle size distribution, 2D and 3D images of the bovine femur bone before and after calcination process is observed under the atomic force microscope (AFM) (NT-MDT Ntegra model, Russian Federation), by recording the interaction forces between the surface and a sharp tip mounted on a cantilever. Samples were exposed to the ultrasonic device before exposure to AFM so that they would not be agglomerated.

\section{Results and Discussion Effect of calcination temperature on characterization of bovine femur bone Fourier transform infrared spectroscopy (FTIR)}

To analyze the changes that occur to the calcination process of bovine femur bone to extract natural hydroxyapatite, FTIR analysis was done at different stages of the process: the washed and dried bone powder (B0) and the bone powder calcined at different temperatures: $900{ }^{\circ} \mathrm{C}(\mathrm{B} 900), 950{ }^{\circ} \mathrm{C}(\mathrm{B} 950), 1000{ }^{\circ} \mathrm{C}$ (B1000), $1050{ }^{\circ} \mathrm{C}(\mathrm{B} 1050)$ and $1100^{\circ} \mathrm{C}(\mathrm{B} 1100)$ were presented in Fig. 1. The B0 spectrum was present amid groups of proteins, namely at $1,639 / \mathrm{cm}$ [16]. The bands specific to $\mathrm{CO}_{3}{ }^{2-}$ group were present in $\mathrm{B} 0$ spectrum

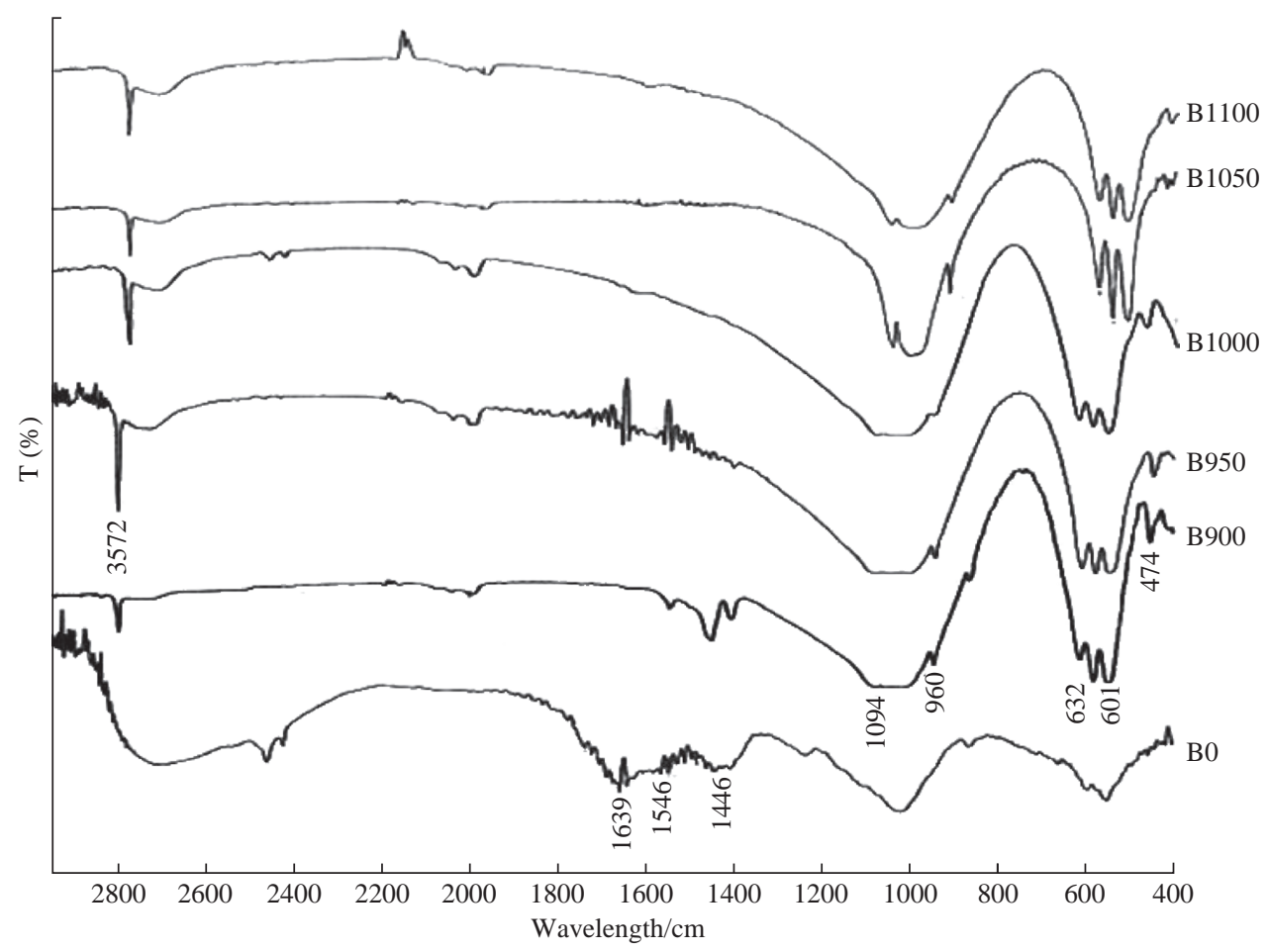

Fig. 1 FTIR for raw bovine femur bone (B0) and calcination at different temperatures: $900{ }^{\circ} \mathrm{C}(\mathrm{B} 900), 950{ }^{\circ} \mathrm{C}(\mathrm{B} 950), 1000{ }^{\circ} \mathrm{C}$ (B1000), $1050{ }^{\circ} \mathrm{C}(\mathrm{B} 1050)$ and $1100{ }^{\circ} \mathrm{C}(\mathrm{B} 1100)$. 
at $1,546 / \mathrm{cm}$ and $1,446 / \mathrm{cm}$. The bands corresponding to the protein group disappeared in the calcination process. The color of bone particles changed from yellowhite to white after the calcination, which implied the decomposition of protein, collagen and other organic substances $[16,17]$ The peaks of bands of the HAp were shown to be at $3,572 / \mathrm{cm}$ and $632 / \mathrm{cm}$ and were attributed to the hydroxyl group $\left(\mathrm{OH}^{-}\right)$; the peaks located at $1,094 / \mathrm{cm}, 960 / \mathrm{cm}, 601 / \mathrm{cm}$ and $474 / \mathrm{cm}$ corresponded to the phosphate group $\left(\mathrm{PO}_{4}{ }^{3-}\right)[18]$. The FTIR band of $1,639 / \mathrm{cm}$ coinciding with the amide of collagen present in the raw bovine femur bone was completely eliminated from the calcined sample.

\section{X-ray diffraction (XRD)}

Fig. 2 demonstrates the XRD patterns of the raw bovine femur bone (B0) and calcined bovine femur bone at $900{ }^{\circ} \mathrm{C}(\mathrm{B} 900), 950{ }^{\circ} \mathrm{C}(\mathrm{B} 950), 1000{ }^{\circ} \mathrm{C}$ (B1000), $1050{ }^{\circ} \mathrm{C}(\mathrm{B} 1050)$ and $1100{ }^{\circ} \mathrm{C}(\mathrm{B} 1100)$. For the calcined samples, there were three main peaks, namely 211 , 112 and 300 planes at $2 \theta$ near $31.8^{\circ}, 32.2^{\circ}$ and $32.9^{\circ}$, respectively $[19,20]$. It was evident that the intensity of diffraction peaks increased with the calcination temperature [21]. Heating at a temperature of $900^{\circ} \mathrm{C}$ resulted in broad diffraction peaks which coincided with a poor crystalline apatite. When increasing the calcination temperature from $900{ }^{\circ} \mathrm{C}$ to $1100{ }^{\circ} \mathrm{C}$, the intensity of diffraction peaks increased and resulted in more intense, sharper and narrower diffraction peaks which denoted to increase the crystallinity and crystal size. It revealed that the amorphous raw bovine femur bone was transformed into crystalline phase with the organic phase and carbonates increasing, as the temperature increased from $900{ }^{\circ} \mathrm{C}$ to $1100{ }^{\circ} \mathrm{C}$. The lattice parameters $\mathrm{c}$ and a could be calculated from the XRD and compared with the standard values of $\mathrm{c}$ and a for hydroxyapatite (Table 1).

Table 1 Values of $\mathrm{c}$ and a for raw bovine femur bone and at different calcination temperatures

\begin{tabular}{ccc}
\hline Sample condition & $\mathrm{a}(\mathrm{nm})$ & $\mathrm{c}(\mathrm{nm})$ \\
\hline Raw & 0.97614 & 0.67819 \\
$900{ }^{\circ} \mathrm{C}$ & 0.94063 & 0.67856 \\
$950{ }^{\circ} \mathrm{C}$ & 0.94090 & 0.69087 \\
$1000{ }^{\circ} \mathrm{C}$ & 0.93190 & 0.68501 \\
$1050{ }^{\circ} \mathrm{C}$ & 0.93047 & 0.69035 \\
$1100{ }^{\circ} \mathrm{C}$ & 0.92566 & 0.67496 \\
\hline
\end{tabular}

\section{Raman spectroscopy}

Fig. 3 demonstrates the Raman spectra of the raw bovine femur bone (B0) and calcined bovine femur bone at $900{ }^{\circ} \mathrm{C}(\mathrm{B} 900), 950{ }^{\circ} \mathrm{C}(\mathrm{B} 950), 1000{ }^{\circ} \mathrm{C}$ (B1000), $1050{ }^{\circ} \mathrm{C}$ (B1050) and $1100{ }^{\circ} \mathrm{C}(\mathrm{B} 1100)$. These samples were dominated by the peaks at 962, 447 and $591 / \mathrm{cm}$ and related to the $\mathrm{PO}_{4}^{3-}[18]$. There was a very strong beak at $962 \mathrm{~cm}$ at $950{ }^{\circ} \mathrm{C}$; the medium intensity

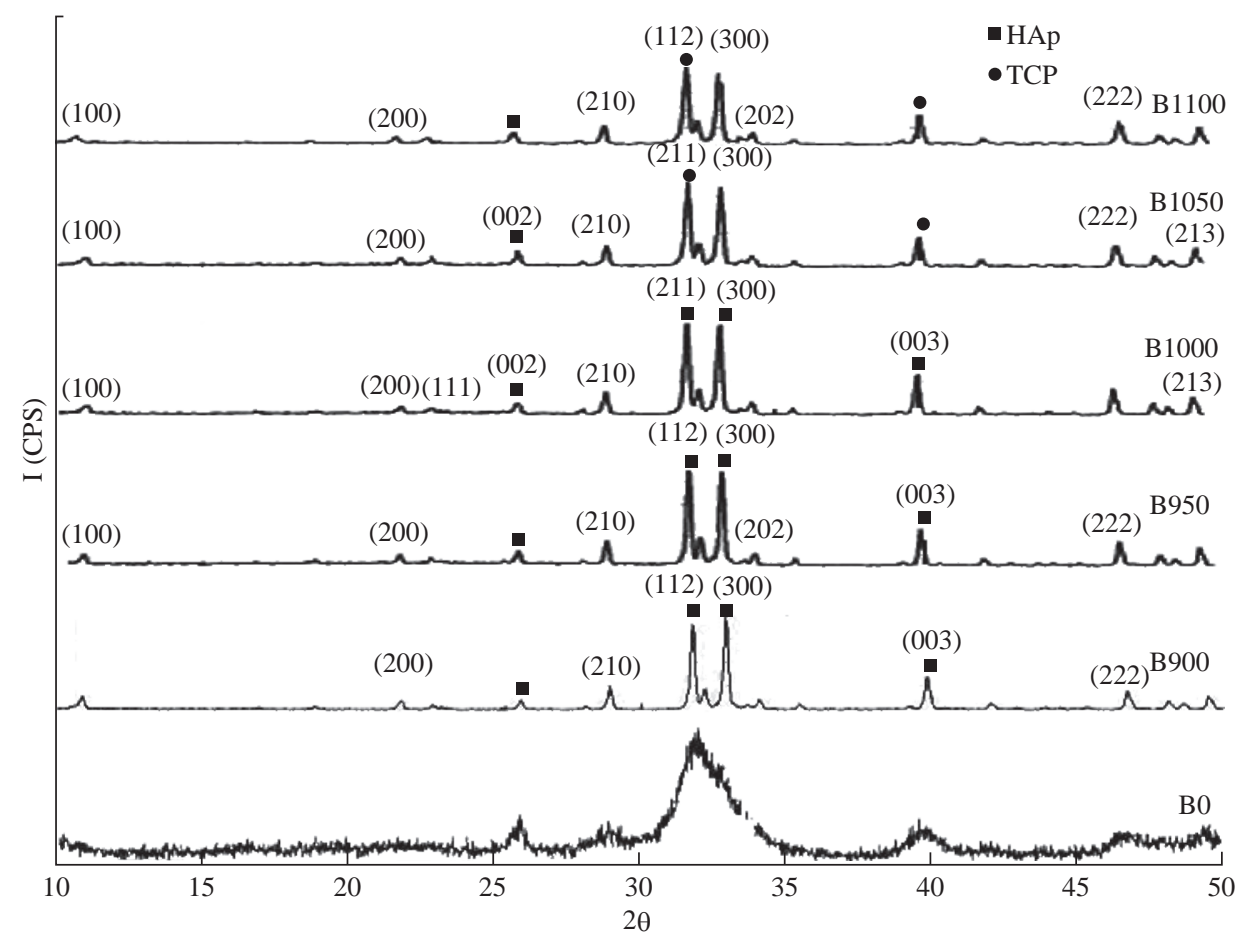

Fig. 2 XRD for raw bovine femur bone (B0) and calcination at different temperatures: $900{ }^{\circ} \mathrm{C}(\mathrm{B} 900), 950{ }^{\circ} \mathrm{C}(\mathrm{B} 950), 1000{ }^{\circ} \mathrm{C}$ (B1000), $1050{ }^{\circ} \mathrm{C}(\mathrm{B} 1050)$ and $1100{ }^{\circ} \mathrm{C}(\mathrm{B} 1100)$. 


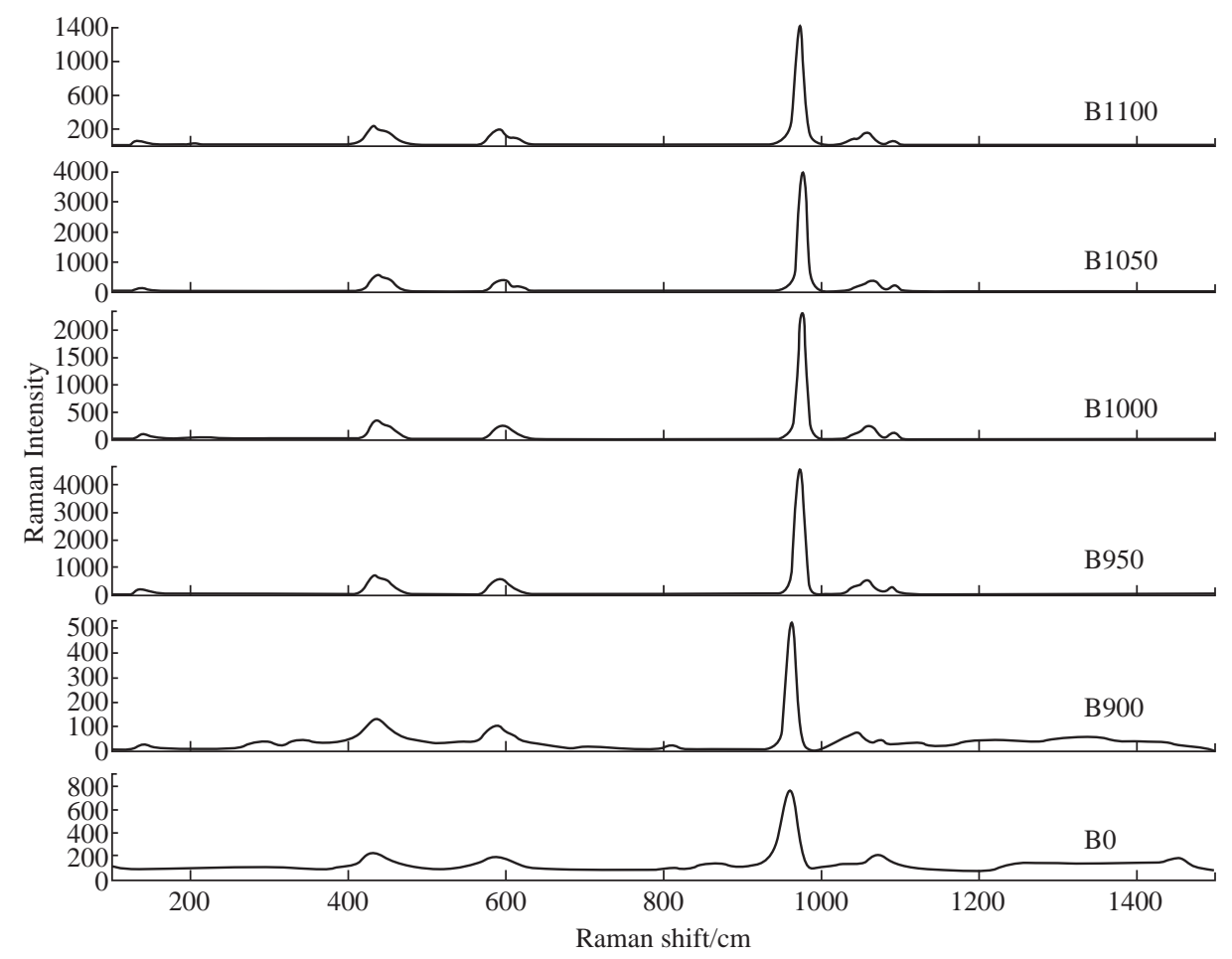

Fig. 3 Raman spectra for raw bovine femur bone (B0) and calcination at different temperatures: $900{ }^{\circ} \mathrm{C}(\mathrm{B} 900), 950{ }^{\circ} \mathrm{C}(\mathrm{B} 950), 1000{ }^{\circ} \mathrm{C}$ (B1000), $1050{ }^{\circ} \mathrm{C}(\mathrm{B} 1050)$ and $1100{ }^{\circ} \mathrm{C}(\mathrm{B} 1100)$.
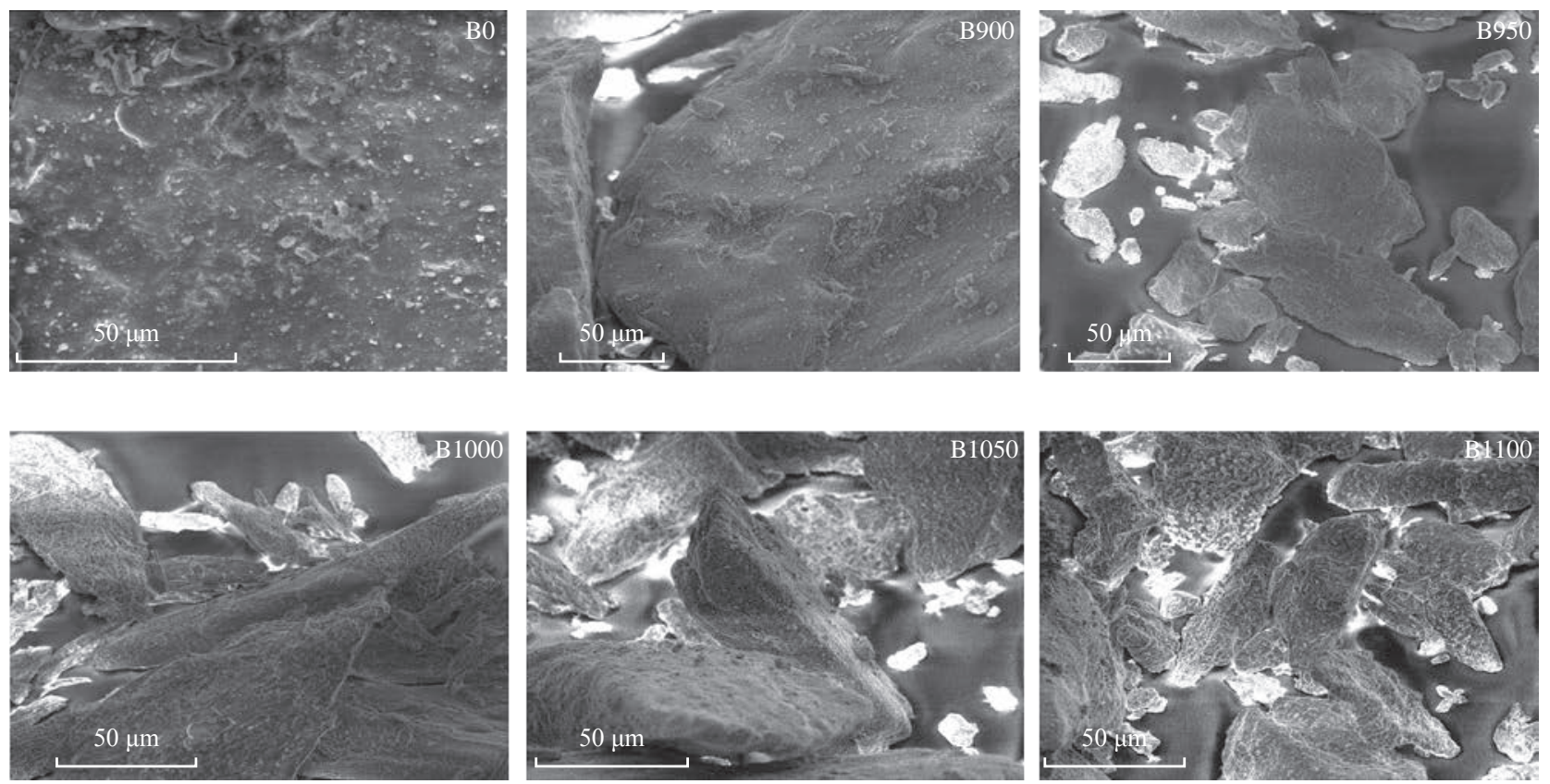

Fig. 4 SEM of raw bovine femur bone (B0) and calcination at different temperatures: $900{ }^{\circ} \mathrm{C}(\mathrm{B} 900), 950{ }^{\circ} \mathrm{C}(\mathrm{B} 950), 1000{ }^{\circ} \mathrm{C}(\mathrm{B} 1000)$, $1050{ }^{\circ} \mathrm{C}(\mathrm{B} 1050)$ and $1100{ }^{\circ} \mathrm{C}(\mathrm{B} 1100)$.

peaks were at 447 and $591 / \mathrm{cm}$, while $\mathrm{CO}_{2}{ }^{3-}$ was present at the peak of $1,073 / \mathrm{cm} \mathrm{[22].} \mathrm{The} \mathrm{spectrum} \mathrm{of} \mathrm{the}$ powder before calcination showed a weak intensity peak at $1,114 / \mathrm{cm}$ which was not observed in the spectrum of the powder after the calcination process. This was related to the presence of organic materials $(\mathrm{C}-\mathrm{H})$ after calcination.

\section{Scanning electron microscopy (SEM)}

Fig. 4 shows the SEM images of the raw bovine femur bone (B0) and calcined bovine femur bone at $900{ }^{\circ} \mathrm{C}(\mathrm{B} 900), 950{ }^{\circ} \mathrm{C}(\mathrm{B} 950), 1000{ }^{\circ} \mathrm{C}$ (B1000), $1050{ }^{\circ} \mathrm{C}(\mathrm{B} 1050)$ and $1100{ }^{\circ} \mathrm{C}(\mathrm{B} 1100)$. The uncalcined sample (B0) exhibited the presence of fat, protein and the interconnected porousness that constituted 
the organic phase. The morphology changed at the surface as calcination temperature increased [22]. For samples calcined at $900{ }^{\circ} \mathrm{C}$, all the fat and protein was removed. When the calcination temperature increased from $900{ }^{\circ} \mathrm{C}$ to $1100{ }^{\circ} \mathrm{C}$, the grain size increased. This
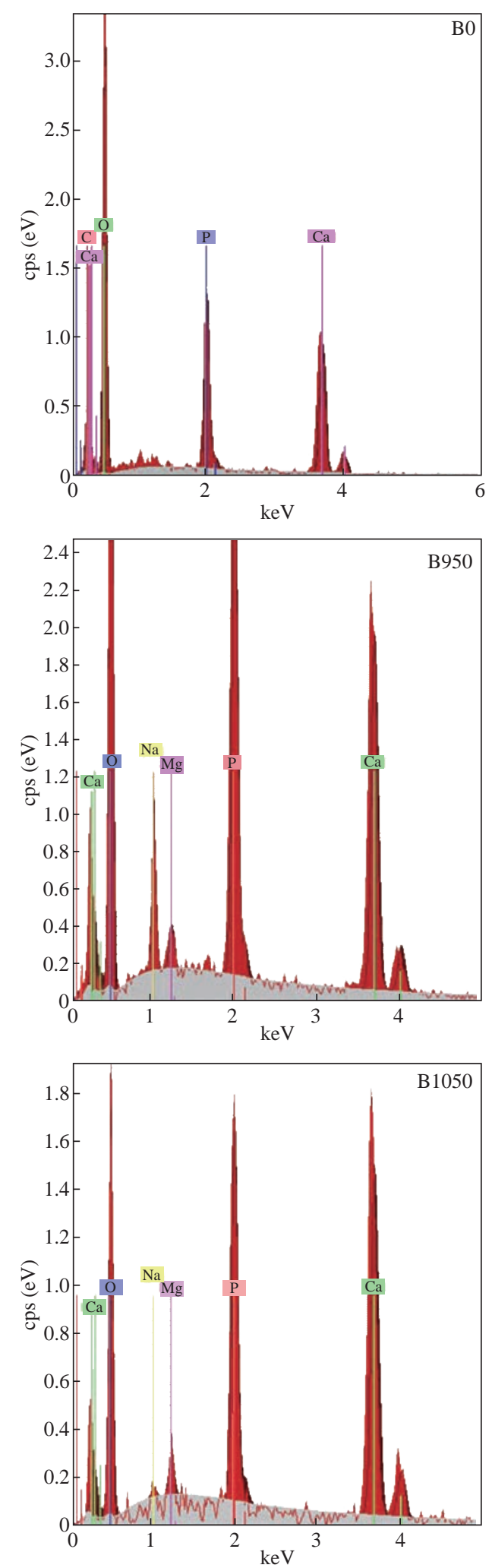

grain growth may be associated with the absorption of heat energy by the particles [19]. The image of SEM showed the formation of micro and sub-micro grains of HAp for calcined sample [23]. The result of EDS (Fig. 5) referred to the presence of elements such as $\mathrm{O}, \mathrm{Mg}$,
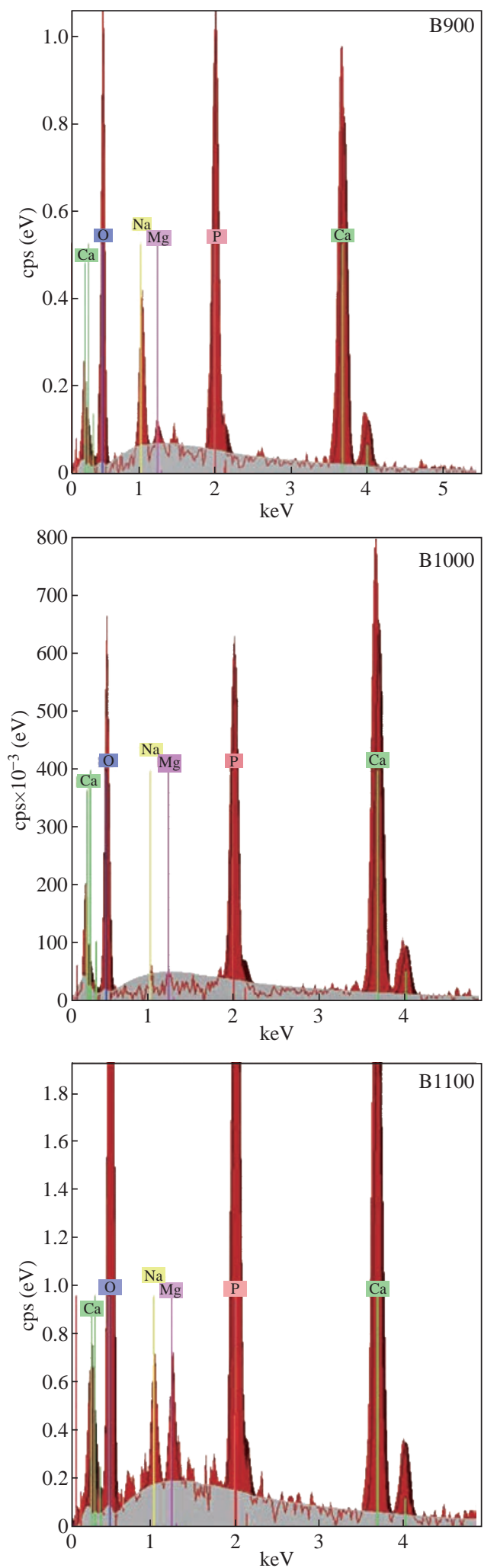

Fig. 5 EDS for raw bovine femur bone (B0) and calcination at different temperatures: $900{ }^{\circ} \mathrm{C}(\mathrm{B} 900), 950{ }^{\circ} \mathrm{C}(\mathrm{B} 950), 1000{ }^{\circ} \mathrm{C}(\mathrm{B} 1000)$, $1050{ }^{\circ} \mathrm{C}(\mathrm{B} 1050)$ and $1100{ }^{\circ} \mathrm{C}(\mathrm{B} 1100)$. 
$\mathrm{Na}$, and $\mathrm{C}$, and these results could be used to determine the value of $\mathrm{Ca} / \mathrm{P}$ as shown in Table 2 .

Table 2 Results of EDS for raw bovine femur bone and at different calcination temperatures

\begin{tabular}{cccc}
\hline \multirow{2}{*}{ Sample condition } & \multicolumn{2}{c}{ Elements $(\mathrm{mol})$} & Molar ratio \\
\cline { 2 - 4 } & $\mathrm{Ca}$ & $\mathrm{P}$ & $\mathrm{Ca} / \mathrm{P}$ \\
\hline Raw & 0.2924 & 0.1785 & 1.6380 \\
$900^{\circ} \mathrm{C}$ & 1.0843 & 0.5039 & 2.1518 \\
$950^{\circ} \mathrm{C}$ & 0.8408 & 0.4929 & 1.7058 \\
$1000{ }^{\circ} \mathrm{C}$ & 1.1891 & 0.3748 & 3.1726 \\
$1050^{\circ} \mathrm{C}$ & 1.1407 & 0.4878 & 2.3384 \\
$1100^{\circ} \mathrm{C}$ & 0.8146 & 0.4652 & 1.7510 \\
\hline
\end{tabular}
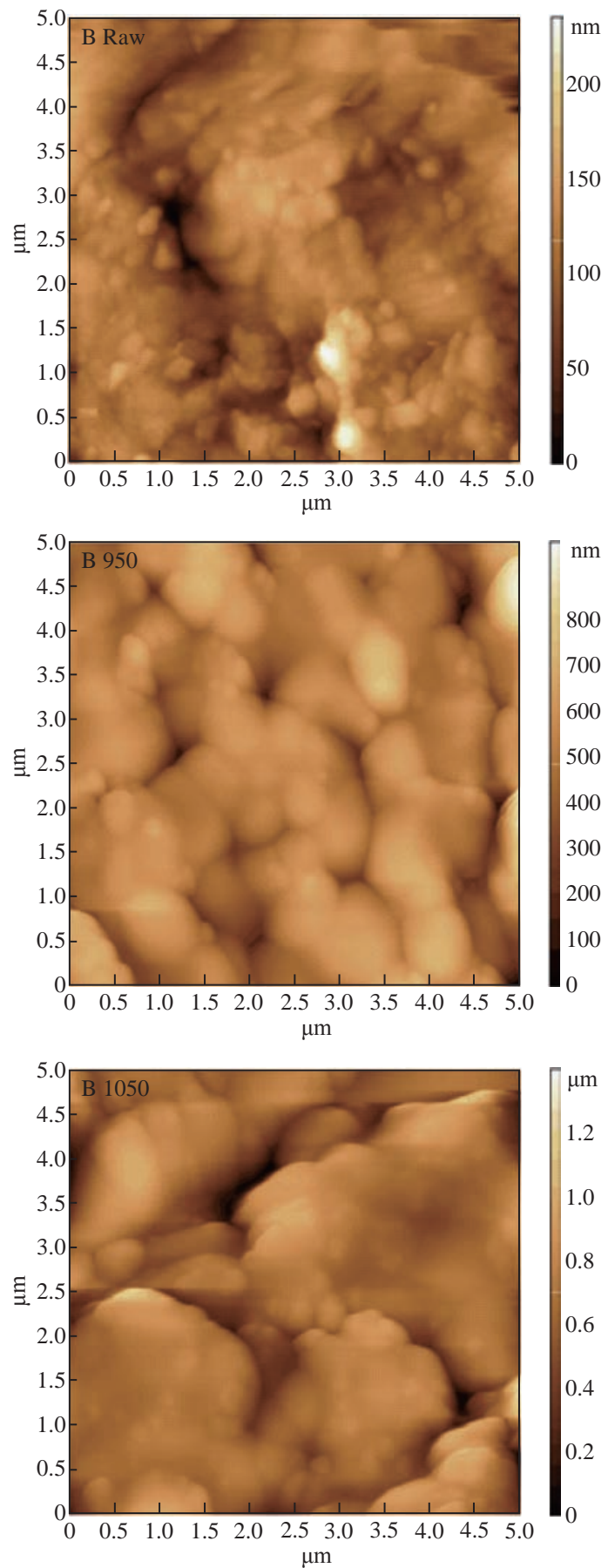

\section{Atomic force microscopy (AFM)}

AFM images of the surface topography of the raw bovine femur bone (B0) and calcined bovine femur bone at $900{ }^{\circ} \mathrm{C}(\mathrm{B} 900), 950{ }^{\circ} \mathrm{C}(\mathrm{B} 950), 1000{ }^{\circ} \mathrm{C}$ (B1000), $1050{ }^{\circ} \mathrm{C}$ (B1050) and $1100{ }^{\circ} \mathrm{C}(\mathrm{B} 1100)$ are shown in Fig. 6. The results revealed an increased particle size with increasing temperatures: 900, 950, 1000,1050 and $1100{ }^{\circ} \mathrm{C}$. And the size of particles changed into micro- and nanoparticle; the shape of particles was irregular before calcination and tended to
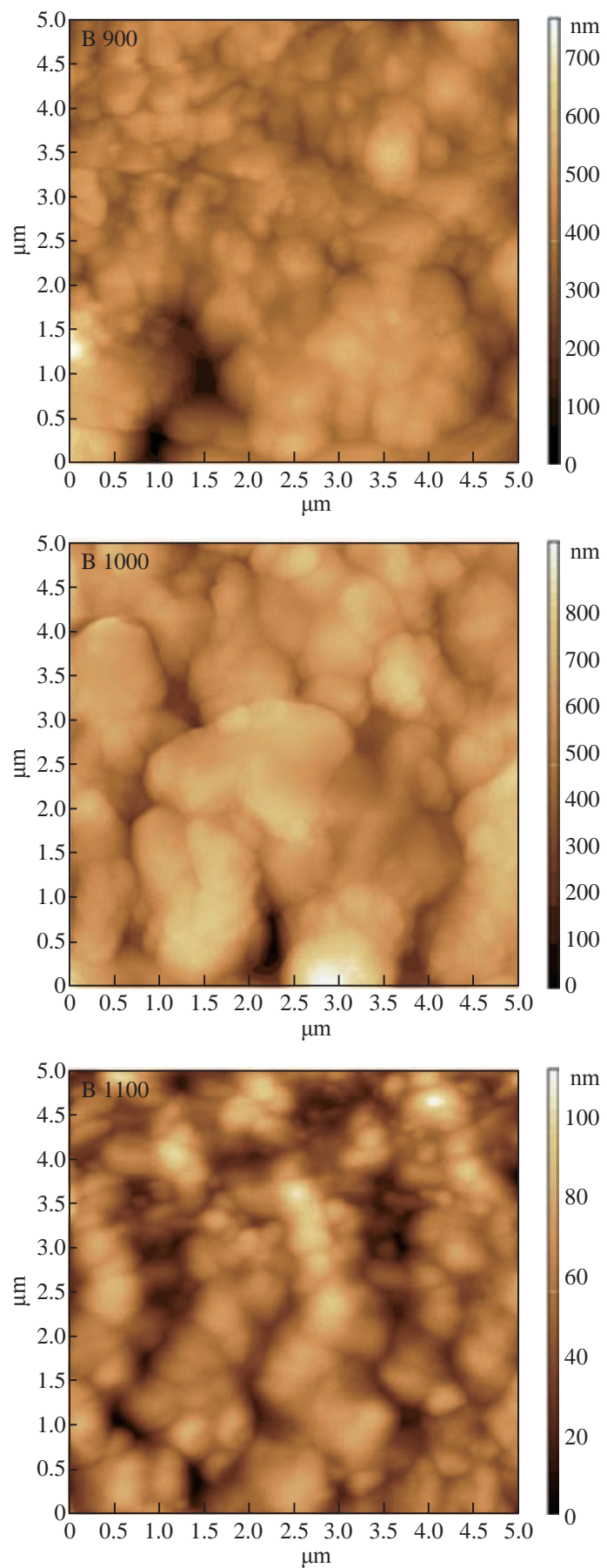

Fig. 6 AFM image for raw bovine femur bone (B0) and calcination at different temperatures: $900{ }^{\circ} \mathrm{C}(\mathrm{B} 900), 950{ }^{\circ} \mathrm{C}(\mathrm{B} 950), 1000{ }^{\circ} \mathrm{C}$ (B1000), $1050{ }^{\circ} \mathrm{C}(\mathrm{B} 1050)$ and $1100{ }^{\circ} \mathrm{C}(\mathrm{B} 1100)$. 
be regular after calcination.

\section{Conclusions}

In this study, through the calcination process of different temperatures at 900,950,1000, 1050 and $1100{ }^{\circ} \mathrm{C}$, natural HAp was obtained from the bovine femur bone. FTIR, XRD and Raman spectra results showed that calcination of bovine femur bone at $900{ }^{\circ} \mathrm{C}$ and above could produce organic free and crystalline natural HAp. SEM results revealed that the grain size increased and the best results were obtained at $950{ }^{\circ} \mathrm{C}$, because the $\mathrm{Ca} / \mathrm{P}$ ratio was 1.7058 , near to the stoichiometric HAp ratio $(\mathrm{Ca} / \mathrm{P}: 1.67)$. The values of $\mathrm{c}$ and a were near to the standard values of $\mathrm{c}=0.6884$ $\mathrm{nm}$ and $\mathrm{a}=0.9418 \mathrm{~nm}$. AFM result showed that the shape of particles tended to be regular after calcination.

\section{Acknowledgments}

The authors gratefully acknowledge the staff of Materials Research Center, Ministry of Science and Technology- Iraq for the characterization facility provided there.

\section{Conflict of Interests}

The authors declare that no competing interest exists.

\section{References}

[1] G. Gergely, F. Wéber, I. Lukács, et al., Preparation and characterization of hydroxyapatite from eggshell. Journal of Ceramics International, 2010, 36: 803-806.

[2] H. Khandelwal, S. Prakash, Synthesis and characterization of hydroxyapatite powder by eggshell. Journal of Minerals and Materials Characterization and Engineering, 2016, 4: 119.

[3] A. Sobczak, Z. Kowalski, and Z. Wzorek, Preparation of hydroxyapatite from animal bones. Journal of Acta of Bioengineering and Biomechanics, 2009, 11: 23-28.

[4] M. Mucalo, Hydroxyapatite (HAp) for biomedical applications. Elsevier, 2015: 10.

[5] M.K. Herliansyah, D.A. Nasution, M.Hamdi, et al., Preparation and characterization of natural hydroxyapatite: A comparative study of bovine bone hydroxyapatite and hydroxyapatite from calcite. Materials Science Forum, 2007, 561: 1441-1444.

[6] V.S. Gshalaev, A.C. Demirchan, Hydroxyapatite: Synthesis, properties, and applications. Nova Science Publishers, 2012: 94.

[7] Y. Oshida, Hydroxyapatite synthesis, properties and applications. Momentum Press, 2015.

[8] S.M. Londoño-Restrepo, C.F. Ramirez-Gutierrez, and A.D. Real, Study of bovine hydroxyapatite obtained by calcination at low heating rates and cooled in furnace air, Journal of Materials Science, 2016, 4431-4441.

[9] M. Akram, R. Ahmed, I. Shakir, et al., Extracting hydroxyapatite and its precursors from natural resources. Journal of Materials Science, 49:1461-1475.

[10] X.Y. Lü, Y.B. Fan, D.C. Gu, et al., Preparation and characterization of natural hydroxyapatite from animal hard tissues. Journal of Key Engineering Materials, 2007, 342: 213-216.

[11] M. Figueiredo, J. Henriques, G. Martins, et al., Physicochemical characterization of biomaterials commonly used in dentistry as bone substitutes: comparison with human bone. J Biomed Mater Res Part B, 2012, 92: 409-419.

[12] A. Sobczak-Kupiec, E. Olender, D. Maline, et al., Effect of calcination of parameters on behavior of bone hydroxyapatite in artificial saliva and its biosafety. Proceedings of 14th IASTEM International Conference. Bangkok, Thailand, Feb. 14, 2016: 25-27.

[13] F. Chenab, Y. Zhub, J. Wub, et al., Nanostructured calcium phosphates: Preparation and their application in biomedicine. Nano Biomed. Eng., 2012, 4.1: 41-49.

[14] N. Nosoudi, A. Hasanzadeh, D. Holman, et al., Calcium phosphate/etidronate disodium biocement: Etidronate, retarder or accelerator. Nano Biomed. Eng., 2014, 6(1): 41-46.

[15] H.L. Jaber, A.S. Hammood, and N. Pravin, Synthesis and characterization of hydroxyapatite powder from natural Camelus bone. Journal of Aust. Ceram. Soc, 2017, 1(1): $1-10$.

[16] E. Kusrini, M. Sontang, Characterization of X-ray diffraction and electron spin resonance: Effects of sintering time and temperature on bovine hydroxyapatite. Journal of Radiat. Phys. Chem., 2012, 81: 118-125.

[17] C.Y. Ooi, M. Hamdi, S. Ramesh, Properties of hydroxyapatite produced by annealing of bovine bone. Journal of Ceramics Int., 2007, 33: 1171-1177.

[18] A.L. Giraldo-Betancur, D.G. Espinosa-Arbelaez, A.D. Real-López, et al., Comparison of physicochemical properties of bio and commercial Hydroxyapatite. Journal of Current Applied Physics, 2013, 13: 1383-1390

[19] W. Khoo1, F.M. Nor1, H. Ardhyananta, et al., Preparation of natural hydroxyapatite from bovine femur bones using calcination at various temperatures. Journal of Procedia Manufacturing, 2015, 2: 196-201.

[20] K. Haberko, M.M. Bucko, J. Brezezinska-Miecznik, et al., Naural hydroxyapatite-its behaviour during heat treatment. J. Eur. Ceram. Soc., 2006, 26: 537-542.

[21] A.M. Sofronia, R. Baies, E.M. Anghel, et al., Thermal and structural characterization of synthetic and natural nanocrystalline hydroxyapatite. Journal of Materials Science and Engineering: C, 2014, 43: 153-163.

[22] R. Murugan, K. Panduranga Rao, and T.S. Sampath Kumar, Heat-deproteinated xenogeneic bone from slaughter house waste: Physcio-chemical properties. Journal of Bull. Mater. Sci., 2003, 26: 523-528.

[23] F. Cristianm G. Ramirez, F. Anderzon, et al., Cooling rate effects on thermal, structural, and microstructural properties of bio-hydroxyapatite obtained from bovine bone, Journal of Biomedical Materials Research Part B: Applied Biomaterials, 2016, 104: 339-344.

Copyright $@ 2017$ Ali Sabea Hammood, Sora Salem Hassan, and Mohammed Talib Alkhafagy. This is an open-access article distributed under the terms of the Creative Commons Attribution License, which permits unrestricted use, distribution, and reproduction in any medium, provided the original author and source are credited. 